\title{
У ЯОГАТА НА СЕМЕЈНИОТ ЕДУКАТОР ВО РАНАТА ИНТЕРВЕНЦИЈА НА ДЕЦАТА СО ПОПРЕЧЕНОСТ
}

\section{Кратка содржина}

На глобално ниво, во последните неколку декади, професионалниот третман на детето со попреченост добива поинакво филозофско гледиште, односно од индивидуален е насочен кон комплексен холистички пристап кон целото семејство. Во современиот пристап на семејно ориентираната рана интервенциија, од особена важност е меѓусебната соработка помеѓу стручнациите, односно трансдисциилинарниот модел каде тимот на стручнации трансдисизиплинарно дава услуги насочени кон семејството и детето. Овие услуги се координирани и интегрирани за да може што подобро да се одговори на комплексните потреби на детето со попреченост и неговото семејство.

Република Македонија со децении се соочува со проблеми во процесот на рана детекција и третман на хицзата со попреченост. Во таа насока спроведовме и истражуване на 47 семејства кои имаат дете со попреченост. Целта на истражуването беше да детектирале кога ги забележале првите проблеми, кој ги забележал и кога започнале со третман. Според добиените резултати во 80\% од примерокот првите знации на нетипичен развој ги забележале нивните родители (почесто мајката), а кај 57\% од децата третманот започнал после една и повеќе години по добиване на дијагнозата.

Проблемите со раната интервенција сметаме дека можат да се надминат со следене на трендот за семејноориентирана рана интервенција, поголема поддрика на семејствата и вклучуване на семејниот едукатор како дел од стручниот тим.

Клучни зборови: СЕМЕЕН ЕДУКАТОР, СЕМЕЈНООРИЕНТИРАНА РАНА ИНТЕРВЕНЦИЈА, СЕМЕЈСТВО, ДЕЦА СО ПОПРЕЧЕНОСТ

\section{Зошто е важна семејната едукација?}

Семејната едукација овозможува зајакнување на членовите на семејството преку развој на вештини, способности, знаења за секој од животните циклуси низ кои поминува семејството. Овозможува зајакнување на семејната кохезија како и интерперсоналните релации преку едукативен и превентивен пристап.

Секој родител доаѓ до момент кога сфаќа дека не ги знае сите одговори за растот и развојот на неговото дете и дека му е неопходна поддр- 
шка која ќе им овозможи на родителите максимадно да го поттикнат развојот на детето, да изградат соодветен емоционален однос заснован на доверба и љубов, да ги препознаат евентуалните „црвени знаменца“ во неговиот развој кои бараат поддршка, советување иди можеби третман од стручни лица. Особено е важно едукацијата која му се нуди на родителот да биде навремена, соодветна и систематски организирана. На тој начин ќе овозможиме соодветна едукација и подготовка на родителите за можните предизвици во родителството.

Во овој момент, во Република Македонија не постои систем за едукација на родители и нивна припрема за родителство. Поради недостатокот на систематизирана едукација, најчесто родителите одговорите на своите дилеми ги бараат кај други родители кои поминале низ тој развоен период на нивното дете или на интернет-портади каде се соочуваат со голем број на неточни информации. Со неорганизираниот пристап се занемарува индивидуалноста во развојот на секое дете и значително се зголемува ризикот од неадекватна едукација, несоодветно информирање на родителот и ризик за правење многу грешки во воспитувањето, растењето и стимулирањето на развојот на детето.

Посебно сензитивен проблем настанува кај родителите кои имаат дете со нетипичен развој. Поради непостоење соодветна информација за очекуваниот развој на детето, често пати нетипичните развојни проблеми се игнорираат од страна на родителите со надеж дека ќе исчезнат сами од себе. Понекогаш, навистина со растење на детето дел од проблемите кои се нетипични за одреден развоен период ќе се надминат како резултат на процесот на созревање и детето ќе има хармоничен развој. Но кај некои развојни проблеми растењето и созревањето на детето нема да доведе до подобрување на состојбата, туку спротивно состојбата ќе се влоши, а детето ја губи можноста за рана интервенција и ран третман. Семејната едукација ќе му овозможи на родителот да прави информирани избори, односно ќе знае каде и кога да побара помош.

\section{Што е рана интервенција?}

Раната интервенција е насочена кон превенција на потешкотиите и нивно ограничување во најмала можна мера, со цел подобрување на здравјето и добросостојбата на детето, нивната компетенција, минимизирање на развојните потешкотии, превенција од функционални регреси, промовирање на адаптирано родителство и подобрување на функционадноста на семејството (Pinjatela i Joković-Oreb, 2010).

Раниот систем на поддршка ги чува семејството и општеството од непожелни случувања (распад на семејството, психосоматски и невротски нарушувања, намалување на нивните работни способности, институционализација на детето и сл.) (Маmić, 2016). Во однос на финансиската исплатливост на истата говорат истражувањата кои упатуваат на тоа дека се- 
кој долар инвестиран во рана интервенција заштедува помеѓу 7 и 21 долар кои треба да се вложат во рамките на услугите што треба да ги понудиме на лицето кое не било вклучено во процесот на рана интервенција (Heckman \& Masterov,2007; Rolnick \& Grunewald,2003).

\section{Семејноориентирана рана интервенција}

Потребата од промена на пристапот е препозната и се применува во многу земји, меѓу кои своја водечка улога имаат САД. Таа своите почетоци ги доживува во почетокот на 70тите години на 20 век. Со помош на овој пристап се обезбедува систем кој треба да одговори на две важни прашања во процесот на рехабилитација, на прашањата КОЈ и КАКО. Прашањето КОЈ се однесува на почитување на изборот на родителите, професионалците вклучуваат поголем број на членови од семејството, ја зајакнуваат семејната сила, промовираат заедништво и соработка со семејствата на индивидуален и флексибилен начин. Подеднакво важно прашање е КАКО кое се однесува на специфичните видови на поддршка и сервисите кои ќе ги понудиме на семејството, како што е одмена на грижа, обезбедување информации (општествени ресурси, бенефиции, соодветни права, информации за природата на проблемите на детето), како и обезбедување емоционална поддршка (пр. советување, поддршка родител на родител, учество во група за поддршка) (Turnbull et al. 2007).

Националната агенција за техничка поддршка во раната интервенција (NECTAC) објавува трендови на сервиси во индивидуалните семејни планови. Од вкупно 17 сервиси идентификувани во извештајот, генерално три можат да се издвојат како сервиси наменети за семејството: а) семеен тренинг, советување и домашна посета, б) поддршка од социјален работник и в) одмена на грижа (Danaher \& Armijo, 2005).

Во САД каде најдобро е развиен овој пристап, истражувањата покажуваат високо задоволство на семејствата корисници на раната интервенција. Bailey и сор. (2004) реализирал телефонско истражување на примерок од 2.600 родители кои имале дете под тригодишна возраст. Според добиените резултати скоро три четвртини од испитаниците сметале дека добиле соодветна поддршка, 91\% од нив ја оцениле услугата како одлична, а 75\% сметале дека раната интервенција имала големо влијание врз целокупниот развој на нивното дете. McBride и Peterson (1997) во своето истражување откриле дека 80\% од интервенциите во домот се однесуваде на разговор со родителите за развојните способности на детето, а $49 \%$ од времето бидо посветено на работа директно со детето.

Во Европа, на барање на германскиот одбор за образование, во 1973 година се основа систем за сеопфатна рана интервенција, кој поддржува регионални, семејни, интердисциплинарни центри за рана интервенција. Во 2002 година 123 регионални центри воспоставиле мрежа за рана помош на сите семејства. Третманот се реализира 50\% амбулантно и 50\% во 
домашни услови. Просечна возраст во која е нуден третманот е 3-4 год. Тој се спроведува според индивидуалните потреби и се состои од една до две сесии неделно во времетраење од две години. Во просек 11 терапевти од раздични подрачја работат во тимовите и меѓу себе се надополнуваат. Таква соработка помеѓ стручњаците бара размена на мислење и идеи за секој случај поединечно, договор за основните концептуални прашања, вредности, цели, специјализирани подрачја и организациски прашања.

Во Норвешка системот за рана интервенција се состои од медицински сестри кои во првите две години ги посетуваат семејствата и децата нудејќи им родителски совети. Оваа поддршка може да трае пододго доколку идентификуваат одреден проблем во развојот на детето (Pašilic, 2019).

Новиот пристап на раната интервенција во центарот на своето интересирање го става разбирањето на детето и семејството на холистички и контекстуален начин, насочувајќи се кон обезбедување поволни можности за учење на детето, а не кон примарно третирање на неговите слаби страни (Dalmau-Montala et al., 2017).

Основни принципи на современиот модел на рана интервенција се:

1. Услугите на рана интервенција се индивидуадизирани, односно раната интервенција е насочена кон силните страни на детето, интересирањата и мотивацијата и се одвива во контекст на неговите секојдневни активности.

2. Раната интервенција е насочена кон семејството, што значи се базира на единствените сили на секое семејство и на нивните приоритети.

3. Раната интервенција се спроведува во тим, стручниот тим и семејството заедно работат во решавање на проблемите и донесувањето на одлуки.

4. Услугите во рамките на раната интервенција се базираат на научно-заснована пракса и пракса која е потврдена со докази.

5. Раната интервенција е насочена кон резултатите.

6. Раната интервенција е во рамнотежа со контекстот во кој детето функционира (Workgroup on Principles and Practices in Natural Environments, 2008).

„Потребно е да обезбедиме квадитетна едукација на родителите за да можат да дадат соодветна поддршка на своето дете. Една од гдавните цели на раната интервенција е да му помогне на родителот да ја сфати природата на проблемите на детето и како тие ќе вдијаат врз понатамошниот развој на детето. На тој начин го зголемуваме капацитетот на родитедите, им помагаме да ги приспособат своите очекувања и вдијаеме врз детските развојни способности“ (Pašilic, 2019).

Во литературата се нагласени три видови на интеракции кои вдијаат врз развојот на детето: трансакцијата родител-дете, семејното организи- 
рање на детското искуство и грижа за здравјето и сигурноста на детето. Во раната интервенција, особено во првата година на детето се препорачува работа на терапевтот во домашни услов. Сите родители кои учествувале во програмата за домашна посета (Home Visitor Program) искажале задоволство од посетата на терапевтот и од напредокот на нивното дете (Guralnick, 2011).

\section{Удогата на родителите во раната интервенција во Република Северна Македонија}

Кога станува збор за родителството, не можеме да зборуваме за добри и лоши одлуки, туку само за информирани избори. Оттука е многу важно нашите родителски одлуки да ги донесуваме врз основа на соодветни, проверени и точни информации. Свеста за клучните прашања поврзани со пречки во развојот на детето и нивното потенцијално вдијание врз семејниот систем е од суштинско значење за процесот на семејноориентирана рана интервенција (Malone et al, 1997).

Системот за рехабилитација и едукација на децата со попреченост во Република Македонија со децении се соочува со проблеми во процесот на рана детекција, односно ран третман на лицата со попреченост. Генерално гледано, раната детекција во нашиот здравствен систем успева само кај оние состојби што се „очигледни“, односно имаат изразени фенотипски или генотипски карактеристики. Како најчести тука би ги издвоиле хромозомопатиите, церебалната парализа, тоталните сензорни оштетувања (тотално слепило, глувост) и др. Голем дел од состојбите кои значително го променуваат функционирањето на дичноста остануваат недијагностицирани долг временски период со што ја губиме можноста за рана интервенција и развивање на максималните потенцијали на детето со попреченост. Во рамките на овие состојби особено значајно место зазема аутизмот, потоа лесната интелектуална попреченост, делумните сетилни оштетувања, проблемите во однесувањето, емоционалните дисфункции и сл.

Слабовидноста и наглувоста, како делумни оштетувања на сетилните органи често не можат да бидат воочени од страна на родителите. Специфичните однесувања кои ги манифестираат овие деца, родителите ги препишуваат на моменталното расположение на детето, интересите, нивната волја и слично. Во Република Македонија, во период од 5 години (од 2014 до 2018) во рамките на проект за лица со пречки во видот, со посебен апарат беше извршен офталмолошки скрининг на 30214 деца на предучилишна и рана училишна возраст, од кои 6587 (21,8\%) се упатени на допо 1 нителен преглед. Во групата на деца упатени на дополнителен преглед детектирани се деца со сериозни проблеми во видот како глауком, катаракта, изразито висока диоптрија, состојби кои доколку се третираат навреме ќе овозможат значително задржување на видот (USAID and LCIF Children with visual impairment project, 2018). 
Пред неколку месеци спроведовме истражување на 45 семејства кои имаат дете со интелектуална попреченост - ученици во посебно основно училиште (ПОУ. Др. Златан Сремац и ПОУ Иднина), со кое ги потврдивме проблемите со кои се соочуваме во раната детекција и дијагностика. Според добиените резултати 17 деца (38\%) добиле дијагноза при раѓање иди до една година од раѓањето, а тоа се деца кои биле дијагностицирани со Даунов синдром (хромозомопатија), церебрална парализа или комбинирани пречки во развојот. Останатите 28 деца (62\%) ја добиле својата дијагноза после втората година, овие деца најчесто имаат дијагноза аутизам со просечна возраст на дијагностицирање од 2,5 години и лесна интелектуална попреченост со просечна возраст на дијагностицирање од 3-6 години. Значајно е да се спомене тоа дека кај децата кои не ја добиле својата дијагноза веднаш по раѓањето, тоа се 36 од децата или 80\%, првите знаци на нетипичен развој ги забележале нивните родители (почесто мајката).

Важен показател во истражувањето ни беше времето поминато од моментот на препознавање на првите знаци кои упатуваат на нетипичен развој, до моментот кога се започнало со третман. Анализата на овој параметар ја правевме на 37 родители, оние кои се изјаснија во однос на ова прашање. На наредниот графикон презентирани се добиените резултати.

Графикон бр.1

Колку време поминало од дијагностицирање до третман на детето:

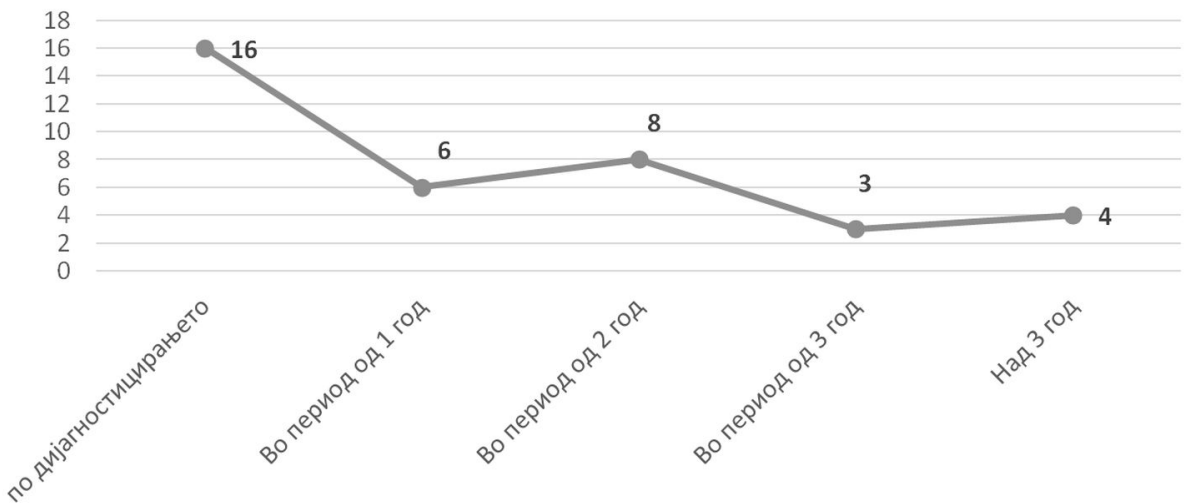

Според добиените податоци 16 родители или 43\% започнале со третман веднаш по забележување на првите знаци за постоење на проблеми во развојот, но останатите 21 родител односно $57 \%$ започнале со третман една, две, три и повеќе години после првите знаци. Ова е сериозен статистички показател за потребата од поддршка на овие семејства. Според резултатите на оваа група на родители, 21 родител ги игнорирале упа- 
тувањата на лекарот или стручниот тим кој ја поставил дијагнозата, ги занемарувале „црвените развојни знаменца“, за кои можеби се надевале дека ќе поминат сами од себе, се плашеле да ја прифатат реалноста или низа други можни причини. Таквиот однос резултирал со дополнителни проблеми во развојот на 21 дете кои ја изгубиле можноста за рана интервенција, односно можноста за максимален индивидуален развој.

\section{Законската регу латива во насока на поддршка на семејствата}

Во 2019 година во Република Македонија беше донесен нов Закон за социјална заштита во кој семејствата и услугите предвидени за семејствата добиваат значајно место. Во оваа насока посебно би ги издвоиле услугите што се нудат во рамките на социјална превенција и социјални услуги.

Во овој дел, односно член 73, дефинирани се услугите на советување кои опфаќаат советодавна работа, со цел превенирање, ублажување и надминување на последиците од настанатите социјални проблеми на поединец и семејство. Како дел од овие услуги дефинирано е и советувањето за родителство.

Во исто време законот предвидува услуги во домот како интегрирани социјални услуги, меѓутоа тие се предвидени за лица со привремено или трајно намален функционален капацитет, но истите не се предвидени за одмена на семејна грижа или поддршка на семејството во домашни услови.

Тргнувајќи од Законот за социјална заштита, би констатирале дека имаме делумно поставена правна рамка за организирање советувалишта за припрема на семејствата за родителство, сепак ни остануваат многу отворени прашања околу начинот на нивна организација, организацијата на трансдисциплинарниот пристап на работа, дефинирање на услугите во домот и поврзување на овие семејни советувалишта со здравствените установи кои нудат здравствена заштита на ризично родени деца.

\section{Препораки}

Дел од проблемите со раната интервенција може да се надминат со вклучување на семејниот едукатор во стручниот тим за рана интервенција. Семејните советувалишта, без раздика дади се во рамите на предучилишни установи, здравствени институции или како самостојни единици може во голема мера да ги подобрат едукативните потенцијали на поширока маса на родители кои ќе знаат кога и каде да се обратат за помош.

Удогата на семејниот едукатор во подобрување на раната интервенција ќе опфати:

Превентивни мерки:

- Подобрување на едукативните потенцијади и вештини на идните родители. На овој начин идните родители ќе имаат информации за развојните периоди низ кои поминува нивното дете, ќе се инфор- 
мираат што да очекуваат и кои индикатори би биле алармантни за барање помош од повисоко ниво;

- Семејниот едукатор би бил достапен за решавање какви било дилеми во однос на развојот на детето и родителството. Сите проблеми за кои семејниот едукатор смета дека се покомплексни и не се во негова надлежност ќе ги решава во консултација со соодветни стручни профили од соодветни институции;

- Следење на развојот на детето во домашни услови, реализирано преку чести домашни посети. Ваквите посети ќе му овозможат на семејниот едукатор подобар увид во семејната динамика, во родителските улоги, следење на развојот и однесувањето на детето во домашни услови.

Во однос на работата со деца со попреченост и нивните семејства, семејниот едукатор ќе овозможи:

- Процена на капацитетите на семејството да одговори на потребите на детето со попреченост;

- Градење врска од доверба со семејните членови и вкдучување на сите членови во процесот на рехабилитација и едукација на детето со попреченост;

- Едукација на родителите за проблемите со кои се соочува нивното дете, за очекувањата и предизвиците;

- Зачувување на менталното здравје на членовите на семејството;

- Индивидуална работа со родителите на деца со попреченост, во насока на организација на стимулативна домашна средина;

- Организирање на групни средби за поддршка на семејни членови (родители и браќа/сестри);

- Организирање на активност родител со родител, воспоставена практика во која искусен родител кој веќе поминал низ одредени предизвици работи со родител кој поминува низ исти или слични предизвици;

- Информирање на родителите за нивните законски права и обврски и помош при остварување на истите;

Во координација со другите профиди од стручниот тим (специјален едукатор и рехабилитатор, психолог, социјален работник и сл.) ќе изготви индивидуален семеен план за работа, кој ќе биде основа во работата со семејните членови. 


\section{Питература:}

Bailey, D., Scarborough, A., HebBeler, K., SPIKER, D., \& MAlliK, S. (2004). National early intervention longitudinal study: Family outcomes at the end of early intervention. Menlo Park, CA: SRI International.

CARPENTER, B. (2001). Families in context: Emerging trends in early intervention and family support. London: David Fulton Publishers.

Dalmau-Montala, M ET AL., (2017). How to implement the family-centered model in early intervention. Anales de PsicologíalAnnals of Psychology, 33 (3), 641-651.

DANAher, J. \& ARmijo, C. (Eds.). (2005). Part C updates (7th ed.). Chapel Hill: University of North Carolina, FPG Child Development Institute, National Early Childhood Technical Assistance Center.

GURALNICK, M. J. (1991). The next decade of research on the effectiveness of early intervention. Exceptional children, 58(2), 174-183.

Heckman, J. J., \& MASTEROV, D. V. (2007). The productivity argument for investing in young children. Applied Economic Perspectives and Policy, 29(3), 446-493.

MALONE, DM., MANDERS, J., STEWART S. (1997)_A rationale for family therapy specialization in early intervention. Available at:

https://www.ncbi.nlm.nih.gov/pubmed/9058553 [Accessed 15.4.2020]

MAMIĆ, P. (2016). Usluge rane intervencije: perspektiva obitelji djece s odstupanjima u psihomotoričkom razvoju (Doctoral dissertation, University of Zagreb. Faculty of Education and Rehabilitation Sciences.).

MCBRIDE, S. L., \& PETERSON, C. (1997). Homebased early intervention with families of children with disabilities: Who is doing what? Topics in Early Childhood Special Education, 17, 209-233.

PAŠILIC, A (2019) Rana intervencija usmjerena na porodici. Available at: file://C:/Users/DELL1/Downloads/Ranaintervencijausmjerenanaporodic updf.pdf [Accessed 2.5.2020]

PinjATElA, R., \& JOKOVIĆ OREB, I. (2010). Rana intervencija kod djece visokorizične za odstupanja u motoričkom razvoju. Hrvatska revija za rehabilitacijska istraživanja, 46(1), 80-102.

ROLNICK, A., \& GRUNEWALD, R. (2003). Early childhood development: Economic development with a high public return. The Region, 17(4), 6-12.

TURNBULL ET AL. (2007) Family support and services in early intervention, Journal of early intervention, 29 (3), 187-206

USAID and LCIF Children with visual impairment project. (2018), Issue 4. Available at: http://cvip.seeu.edu.mk/web/lcif-newsletter/ [Accessed 12.4.2020]

WORKGROUP ON PRINCIPLES AND PRACTICES IN NATURAL ENVIRONMENTS, OSEP TA Community of Practice: Part C Settings. (2008, February). Agreed upon practices for providing early intervention services in natural environments. 
Available at: http://www.ectacenter.org/ pdfs/topics/families/AgreedUponPractices_FinalDraft2_01_08.pdf [Accessed 2.5.2020]

ЗАКОН ЗА СОЦИЈАЯНА ЗАШТИТА. (2019), Службен весник на РСМ, бр. 104. Available at: mtsp.gov.mk/content/pdf/zakoni/2019/28.5_zakon_SZ.pdf [Accessed 3.5.2020] 